\title{
RADIOCARBON DATING OF GROUNDWATER IN A CONFINED AQUIFER IN SOUTHEAST ARIZONA
}

\author{
FREDERICK N. ROBERTSON
}

\author{
U.S. Geological Survey, 375 South Euclid Avenue, Tucson, Arizona 85719 USA
}

\begin{abstract}
Radiocarbon, $\delta^{13} \mathrm{C}$ and major-element data were used to construct a geochemical framework for interpretation of the hydrological flow system in the lower San Pedro basin, southeastern Arizona, USA. The ${ }^{14} \mathrm{C}$ and major-element data show a regional confined aquifer that extends throughout most of the basin. Groundwater ages, after correcting for chemistry, are greater than $10 \mathrm{ka}$ BP. The groundwater ages do not increase in a downvalley direction, the assumed direction of groundwater movement in most intermontane basins in the region, but along general flow paths normal to the mountains toward the center of the basin. Recharge to the confined aquifer originates from infiltration of precipitation and runoff near the alluvium-mountain contact along the Galiuro Mountains and is discharged by evapotranspiration along the center of the basin. The hydrogeological concept of the ${ }^{14} \mathrm{C}$ model is supported by the water chemistry and by the mass transfer defined by the chemical model. Weathering of primary silicate minerals in the confined aquifer does not occur downvalley, but only along the direction of flow. Hydraulic conductivities calculated for the aquifer from ${ }^{14} \mathrm{C}$ velocities are about an order of magnitude slower than those determined through hydrological methods. The lower hydraulic-conductivity values are attributed to a thick confining layer overlying the discharge area along the San Pedro River.
\end{abstract}

\section{INTRODUCTION}

The San Pedro Valley extends about $200 \mathrm{~km}$ from the international boundary with Mexico northward to Winkelman, Arizona, USA, where the San Pedro River joins the Gila River. The valley is divided into an upper and a lower basin at about its mid-point. The lower San Pedro basin extends about $105 \mathrm{~km}$ from The Narrows, a point where the mountains form a topographic restriction, to Winkelman (Fig. 1). The San Pedro River flows northward along the axis of the valley and drains the basin, an area of about $5300 \mathrm{~km}^{2}$ (Roeske \& Werrell 1973).

The lower San Pedro basin is bordered on the west by the Rincon, Santa Catalina and Tortilla Mountains, and on the east by the Galiuro Mountains. Altitudes of the mountains are more than $2,700 \mathrm{~m}$ above sea level and rise above the basin floors as much as $1,500 \mathrm{~m}$. The climate of the area is semi-arid, with hot summers and mild winters. Mean annual precipitation ranges from a maximum of more than $760 \mathrm{~mm}$ in the Santa Catalina Mountains and more than $630 \mathrm{~mm}$ in the Galiuro Mountains to less than $300 \mathrm{~mm}$ in the basin. Winter precipitation originates to the northwest, and generally is the result of regional storms of low intensity and long duration. Summer precipitation, which originates from the south, occurs as high-intensity, short-duration thunderstorms and supplies more than $60 \%$ of the annual precipitation. Owing to elevation variations, the valley hosts a variety of vegetation.

In this paper I discuss the use of chemical and isotope data to evaluate the hydrology of the lower San Pedro basin. Major-ion, ${ }^{14} \mathrm{C},{ }^{13} \mathrm{C}$, and ${ }^{3} \mathrm{H}$ data were collected to determine geochemical processes, direction of groundwater movement, groundwater ages, and groundwater velocities. Areas of recharge, discharge and mixing defined by the chemical and isotope data are related to the hydrological flow system. I compare geochemical interpretations to the conceptual model of the flow system based on hydrological data.

\section{Hydrogeology}

The Rincon, Santa Catalina and Tortilla Mountains consist primarily of granite and gneiss with occasional outcrops of consolidated sedimentary rocks. The Galiuro Mountains consist almost completely of acidic and intermediate volcanic rocks. The alluvial basin-fill deposits, derived from the surrounding mountains, consist of clastic sediments, evaporites and stream alluvium. A lower 


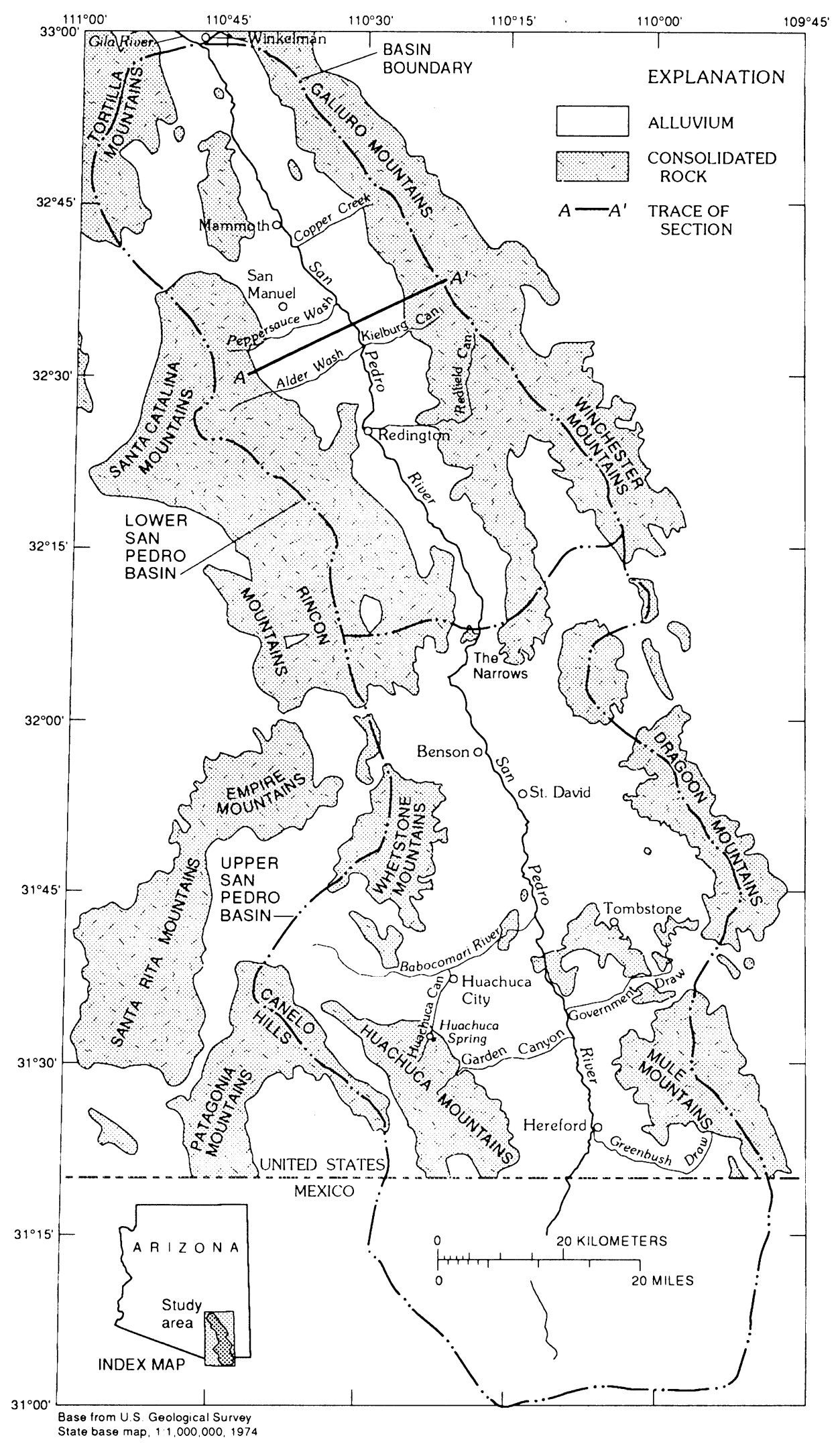

Fig. 1. Location of the upper and lower San Pedro basins 
unit and an upper unit have been identified in the lower basin (Fig. 2). The lower unit was deposited under internal drainage conditions, is the more highly faulted and deformed and contains more consolidated and fine-grained sediments than the upper unit. The upper unit generally is coarser grained, and some sediments may have accumulated at a time of through-flowing drainage conditions (Pool 1986; Laney \& Hahn 1987). As in most basins in southeastern Arizona, the alluvial deposits generally grade from coarse material near the mountain fronts to finer-grained sand, silt and clay near the valley axis. Location of fault boundaries, precipitation variations, relief of the depositional area and shifting of stream channels during deposition create a varied sediment distribution and a highly complex flow system.

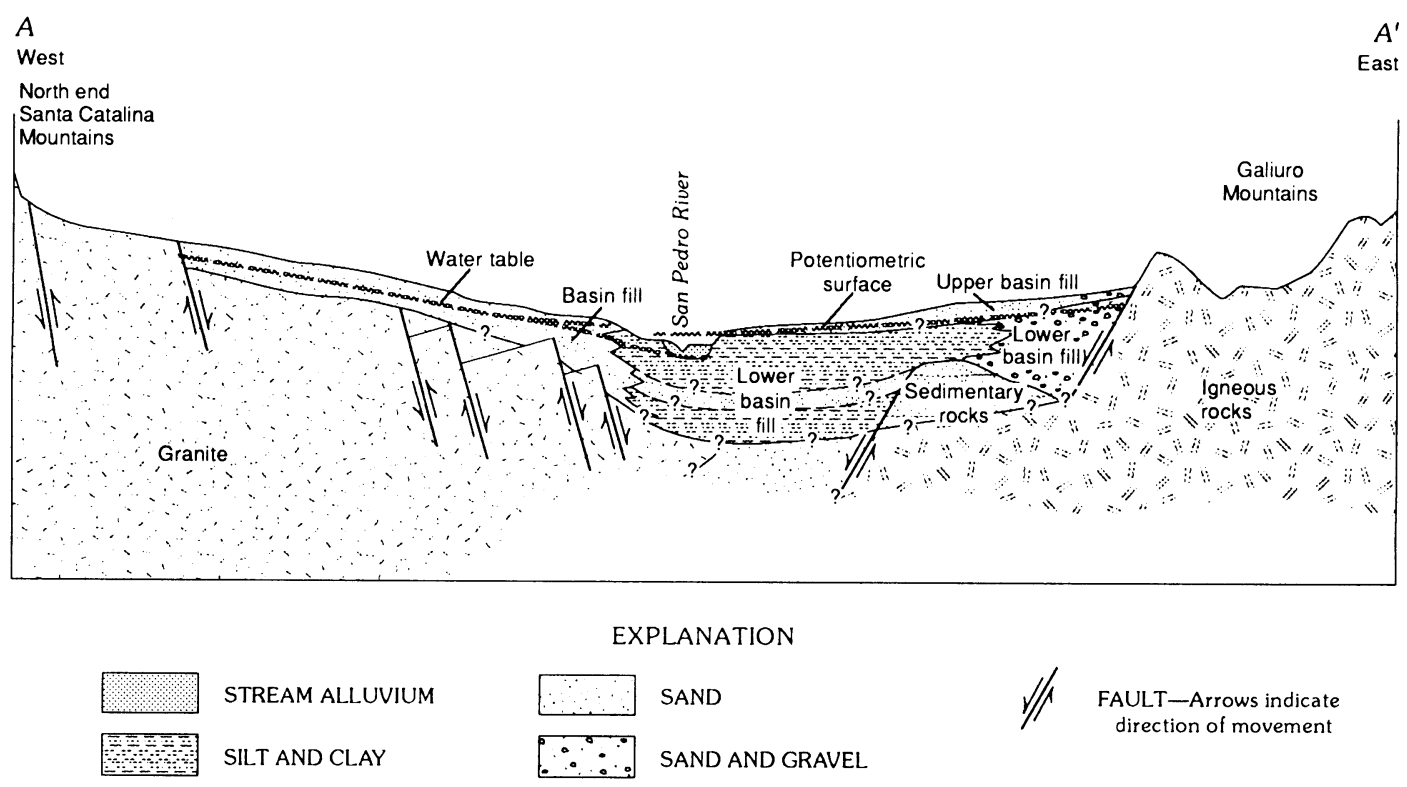

Fig. 2. Schematic diagram of transverse section of lower San Pedro basin. Modified from Halpenny et al. (1952).

The major aquifer consists of coarse-grained deposits of the lower basin fill and possibly pre-Basin and Range sediments overlain by a confining unit ranging from 25 to $400 \mathrm{~m}$ thick (Pool 1986). The flood-plain deposits along the San Pedro River consist of mixtures of sand, gravel and silt, and also constitute an unconfined local aquifer recharged primarily by river seepage (Roeske \& Werrell 1973). Groundwater occurs under confined conditions in an area from Redington to near Winkelman, covering a large part of the basin (Fig. 3). Artesian pressure at depths of $90 \mathrm{~m}$ near Redington to $460 \mathrm{~m}$ near Mammoth is sufficient for wells to flow at rates of about 0.5 to 30 liters $\mathrm{s}^{-1}$. Groundwater is recharged by precipitation and runoff that infiltrates along the Galiuro Mountains on the east, and the Tortilla, Santa Catalina and Rincon Mountains on the west and, as indicated by water-level data, flows normal to the mountains toward the basin axis (Fig. 4), where it is discharged mainly by evapotranspiration.

\section{GEOCHEMISTRY AND ISOTOPIC COMPOSITIONS OF THE GROUNDWATER}

Water samples were collected from selected wells and springs and analyzed for major ions and isotopes (Table 1). Temperature, $\mathrm{pH}$ and alkalinity were determined in the field (Brown, Skougstad \& Fishman 1970; Barnes 1964). ${ }^{14} \mathrm{C}$ and ${ }^{13} \mathrm{C}$ contents were analyzed in the Radiocarbon Dating Laboratory, Laboratory of Isotope Geochemistry, The University of Arizona, and are reported in 


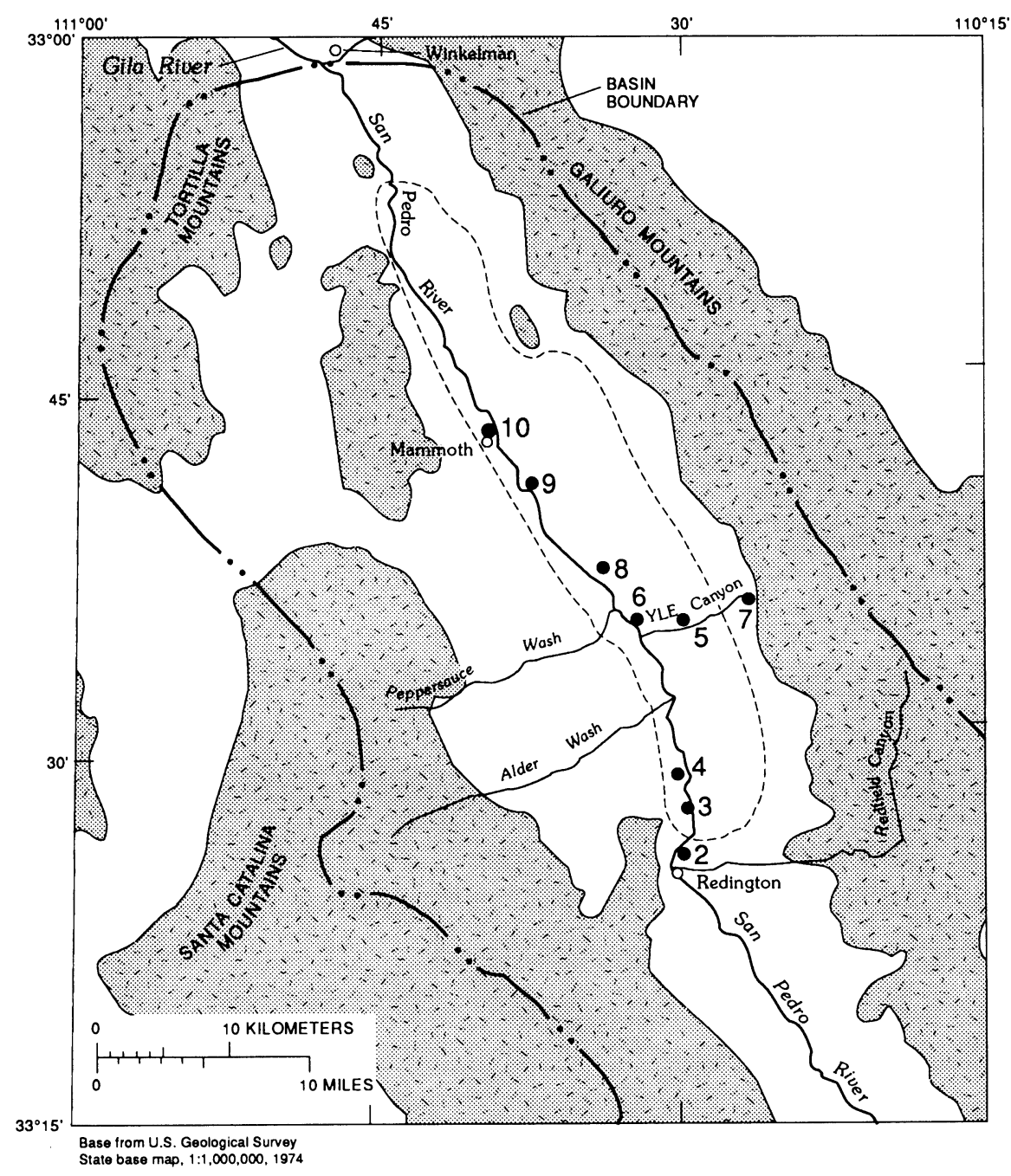

EXPLANATION
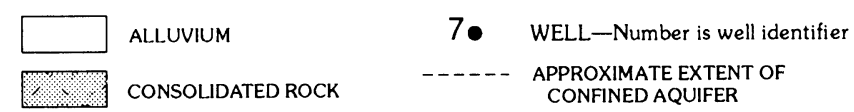

Fig. 3. Location of wells sampled and approximate extent of confined aquifer in Lower San Pedro basin

percent modern carbon (pMC) and per mil (\%o) relative to Chicago Peedee Belemnite (PDB), respectively. Samples for ${ }^{14} \mathrm{C}$ analysis were precipitated in the field or delivered to the laboratory within $24 \mathrm{~h}$ for precipitation. Samples were analyzed for chemistry and tritium by the U.S. Geological Survey Central Laboratory in Arvada, Colorado. Tritium analyses are reported in tritium units (TU) and have a detection limit of $0.3 \mathrm{TU}$.

The groundwater composition throughout much of the basin ranges from a dilute sodium bicarbonate type in the south to a sodium mixed anion type in the north, with dissolved solids increasing from about 250 to more than $500 \mathrm{mg} \mathrm{liter}^{-1}$. The increase in dissolved solids is not a result of down-valley movement of water along the basin axis but rather of movement of water along flow 


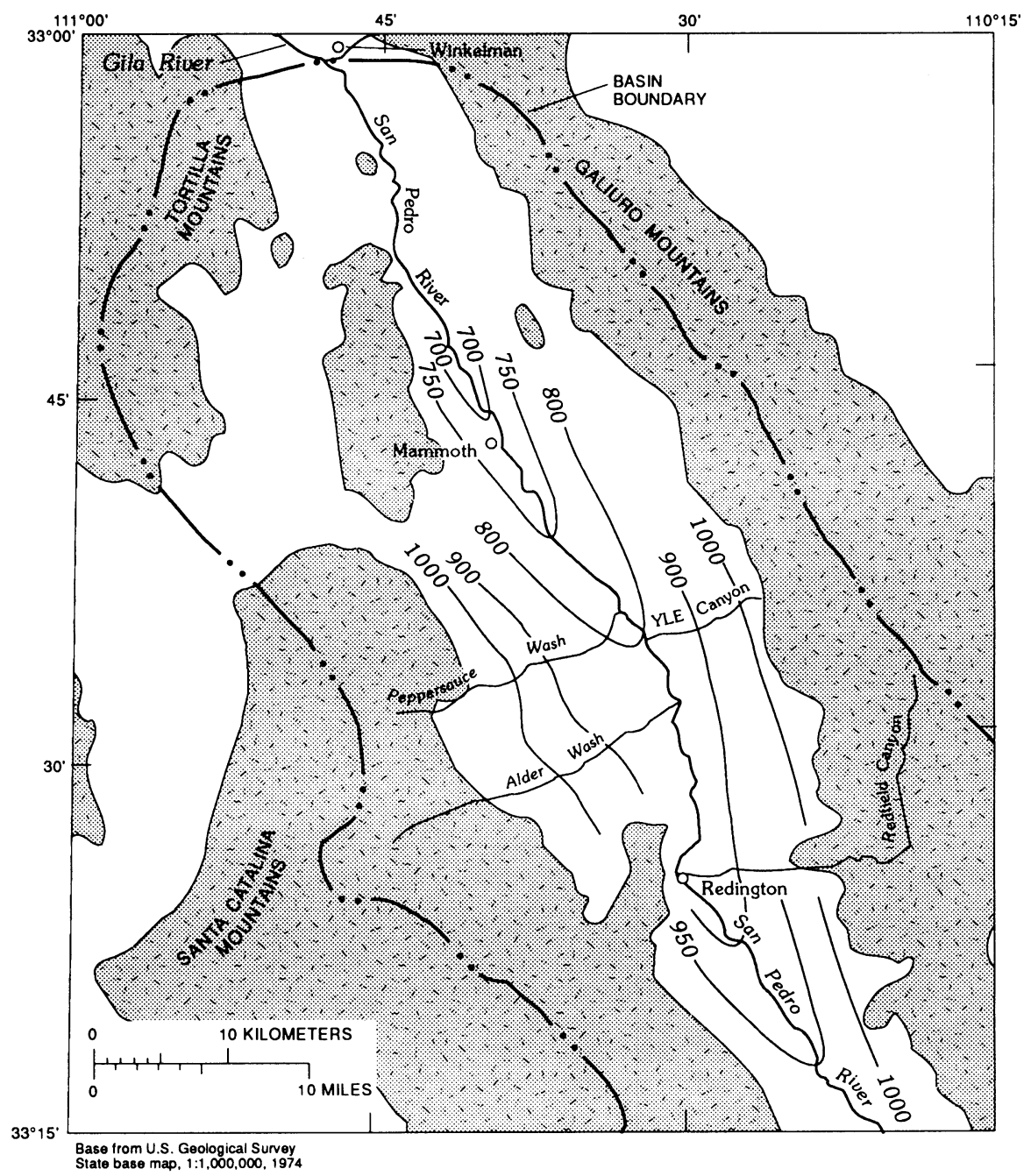

EXPLANATION

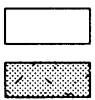

ALLUVIUM

-900- ALTITUDE OF POTENTIOMETRIC

CONSOLIDATED ROCK

Fig. 4. Location of potentiometric surface in the lower San Pedro basin. Modified from Roeske and Werrell (1973).

paths from recharge near the mountains to the basin center. Water chemistry further indicates that groundwater in the confined aquifer originates near the Galiuro Mountains on the east and not the Catalina Mountains on the west. This is supported by similarities in the small $\mathrm{Ca}$ and $\mathrm{Mg}$ concentrations, and in the high fluoride concentrations in the confined aquifer along the San Pedro River, and between the river and the Galiuro Mountains. In contrast, groundwater between the river and the Catalina Mountains has higher $\mathrm{Ca}, \mathrm{Mg}$ and $\mathrm{HCO}_{3}^{-}$concentrations, lower $\mathrm{F}^{-}$concentrations and lower temperatures. Under closed conditions of the confined aquifer, $\mathrm{Mg}$ and $\mathrm{Ca}$ are removed by montmorillonite and calcite precipitation, and $\mathrm{HCO}_{3}^{-}$is lowered by calcite precipitation and higher 
TABLE 1. Isotopic and chemical analyses of groundwater from the lower San Pedro basin. (Concentrations in mmol liter ${ }^{-1}$, except as indicated)

\begin{tabular}{|c|c|c|c|c|c|c|c|c|c|c|c|c|c|c|c|c|c|c|c|}
\hline $\begin{array}{l}\text { Well } \\
\text { no. }\end{array}$ & $\begin{array}{l}\text { Well } \\
\text { depth } \\
\text { (m) }\end{array}$ & $\begin{array}{l}\text { Date } \\
\text { sampled }\end{array}$ & TDIC* & $\begin{array}{l}\delta^{13} \mathrm{C}^{* *} \\
(\%)\end{array}$ & $\begin{array}{l}{ }^{14} \mathrm{C}^{* * *} \\
(\mathrm{pMC})\end{array}$ & $\begin{array}{l}{ }^{3} \mathrm{H} \\
(\mathrm{TU})\end{array}$ & $\begin{array}{l}\mathrm{T} \\
\left({ }^{\circ} \mathrm{C}\right)\end{array}$ & $\begin{array}{l}\text { Field } \\
\mathrm{pH}\end{array}$ & $\begin{array}{l}\text { TDS } \\
(\mathrm{mg} \\
\left.\text { liter }^{-1}\right)\end{array}$ & $\mathrm{Ca}^{2+}$ & $\mathrm{Mg}^{2+}$ & $\mathrm{Na}^{+}$ & $\mathrm{K}^{+}$ & $\mathrm{Cl}^{-}$ & $\mathrm{SO}_{4}^{2-}$ & $\mathrm{HCO}_{3}^{-}$ & $\mathrm{F}$ & $\mathrm{NO}_{3}^{-}$ & $\mathrm{SiO}_{2}$ \\
\hline $1^{\dagger}$ & $\ldots$ & $07-02-80$ & 5.62 & -12.7 & 86.8 & 8.4 & 19.8 & 7.1 & 425 & 1.946 & 0.535 & 0.218 & 0.026 & 0.130 & 0.188 & 4.802 & 0.016 & 0.021 & 0.200 \\
\hline 2 & 107 & $08-30-81$ & 2.43 & -10.8 & 37.9 & --- & 21.5 & 8.5 & 312 & 0.325 & 0.021 & 2.784 & 0.041 & 0.451 & 0.323 & 2.398 & 0.089 & $\cdots$ & 0.583 \\
\hline 3 & 154 & $08-07-82$ & 2.26 & -12.4 & 23.6 & --. & 23.4 & 8.3 & 272 & 0.250 & 0.017 & 2.567 & 0.041 & 0.257 & 0.185 & 2.229 & 0.100 & 0.093 & 0.483 \\
\hline 4 & 118 & $08-07-82$ & 2.39 & -11.8 & 22.0 & $<.3$ & 26.5 & 8.3 & 293 & 0.232 & 0.045 & 2.784 & 0.046 & 0.310 & 0.198 & 2.393 & 0.105 & 0.114 & 0.583 \\
\hline 5 & 183 & $11-27-81$ & 1.92 & -10.2 & 23.6 & $<.3$ & 44.5 & 8.1 & 530 & 0.449 & 0.017 & 5.655 & 0.097 & 1.100 & 1.666 & 1.966 & 0.374 & -.-- & 0.865 \\
\hline 6 & 85 & $12-02-81$ & 2.00 & -9.7 & 25.4 & 1.3 & 40.5 & 8.1 & 510 & 0.524 & 0.033 & 5.220 & 0.092 & 1.044 & 1.562 & 2.032 & 0.437 & ---- & 0.766 \\
\hline 7 & --- & $11-06-82$ & 2.02 & -19.5 & 120.7 & 25.6 & 21.0 & 6.5 & 255 & 0.724 & 0.358 & 0.783 & 0.043 & 0.265 & 0.697 & 1.213 & 0.011 & 0.034 & 0.782 \\
\hline 8 & 265 & $11-28-80$ & 2.03 & -10.5 & 18.7 & --- & 33.0 & 8.5 & 479 & 0.190 & 0.020 & 4.785 & 0.092 & 0.818 & 1.041 & 1.967 & 0.300 & 0.023 & 0.599 \\
\hline 9 & 453 & $11-28-80$ & 1.78 & -10.6 & 19.6 & $<.3$ & 42.0 & 8.4 & 417 & 0.245 & 0.003 & 5.655 & 0.064 & 1.241 & 1.458 & 1.803 & 0.316 & 0.023 & 0.557 \\
\hline 10 & 122 & $12-27-82$ & 2.11 & -9.8 & 9.0 & $<.3$ & --- & 9.5 & 381 & 0.093 & 0.004 & 4.355 & 0.021 & 0.452 & 0.553 & 2.229 & 0.169 & 0.071 & 0.749 \\
\hline
\end{tabular}

*Calculated.

**Analyses by Radiocarbon Dating Laboratory, Laboratory of Isotope Geochemistry, The University of Arizona, Tucson, Arizona. $\delta^{13} \mathrm{C}$ relative to Peedee Belemnite.

${ }^{\dagger}$ Spring in upper San Pedro basin.

TABLE 2. Summary of mass transfer for groundwater from the lower San Pedro basin. (Values in mmol liter ${ }^{-1}$; reactants are positive and products are negative)

\begin{tabular}{|c|c|c|c|c|c|c|c|c|c|c|c|c|c|c|c|c|}
\hline $\begin{array}{l}\text { Sample } \\
\text { no. }\end{array}$ & $\mathrm{O}_{2}$ & $\mathrm{CO}_{2}$ & Calcite & $\begin{array}{l}\text { Dolo- } \\
\text { mite }\end{array}$ & $\begin{array}{l}\text { Ande- } \\
\text { sine }\end{array}$ & $\begin{array}{l}\text { K-feld- } \\
\text { spar }\end{array}$ & $\begin{array}{l}\text { Horn- } \\
\text { blende }\end{array}$ & Silica & Halite & Gypsum & Fluorite & Ilmenite & $\begin{array}{l}\text { Mont- } \\
\text { morill- } \\
\text { onite }\end{array}$ & $\begin{array}{l}\text { Kao- } \\
\text { linite }\end{array}$ & Goethite & $\begin{array}{l}\text { Ion ex- } \\
\text { change }\end{array}$ \\
\hline 1 & 0.02 & 3.42 & 1.12 & 0.54 & 0.13 & 0.04 & 0.06 & -0.11 & 0.13 & 0.19 & 0.01 & 0.00 & -0.14 & -0.04 & -0.03 & 0.00 \\
\hline 2 & 0.23 & --- & -3.19 & 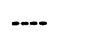 & 3.27 & 0.38 & 0.82 & -0.31 & 0.32 & 0.14 & 0.04 & 0.08 & -2.79 & -0.73 & -0.15 & 0.03 \\
\hline 3 & 0.26 & ---- & -3.36 & -.-- & 3.49 & 0.41 & 0.93 & -0.52 & 0.13 & 0.00 & 0.04 & 0.09 & 3.00 & -0.78 & -0.21 & 0.00 \\
\hline 4 & 0.25 & --- & -3.23 & $\ldots$ & 3.38 & 0.36 & 0.90 & -0.37 & 0.18 & 0.01 & 0.05 & 0.09 & -2.89 & -0.75 & -0.21 & 0.06 \\
\hline 5 & 0.27 & --- & -3.70 & $\ldots$ & 3.53 & 0.47 & 0.97 & -0.23 & 0.97 & 1.47 & 0.18 & 0.09 & -3.08 & -0.80 & -0.23 & 1.05 \\
\hline 6 & 0.25 & --- & -3.62 & $\ldots$ & 3.39 & 0.45 & 0.92 & -0.29 & 0.91 & 1.36 & 0.21 & 0.09 & -2.95 & -0.77 & -0.21 & 0.91 \\
\hline 7 & --.- & --- & 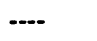 & ---- & $\cdots$ & --- & --- & --- & $\cdots$ & $\cdots$ & $\cdots$ & --- & $\cdots$ & ---.- & $\cdots$ & --- \\
\hline 8 & 0.26 & --- & -3.59 & $--\cdot$ & 3.52 & 0.46 & 0.96 & -0.51 & 0.69 & 0.85 & 0.14 & 0.09 & -3.07 & -0.80 & -0.23 & 0.76 \\
\hline 9 & 0.27 & --- & -3.84 & ---- & 3.65 & 0.45 & 0.99 & -0.55 & 1.11 & 1.27 & 0.15 & 0.09 & -3.16 & -0.82 & -0.24 & 0.94 \\
\hline 10 & 0.30 & -.-- & -3.51 & -.-. & 3.91 & 0.43 & 1.10 & -0.43 & 0.32 & 0.37 & 0.08 & 0.10 & -3.38 & -0.88 & -0.30 & 0.60 \\
\hline
\end{tabular}

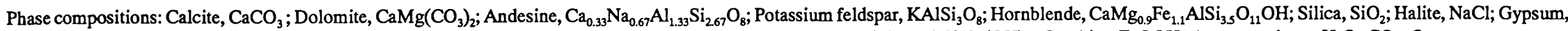
$\mathrm{CaSO}_{4}$; Fluorite, $\mathrm{CaF}_{2}$; Ilmenite, FeTiO ${ }_{3}$; Montmorillonite, $\mathrm{Ca}_{0.17} \mathrm{~K}_{0.13} \mathrm{Mg}_{0.45} \mathrm{Fe}_{0.30} \mathrm{Ti}_{0.03} \mathrm{Al}_{1.47} \mathrm{Si}_{3.80} \mathrm{O}_{10}(\mathrm{OH})_{2} ; \mathrm{Kaolinite}, \mathrm{Al}_{2} \mathrm{Si}_{2} \mathrm{O}_{5}(\mathrm{OH})_{4} ; \mathrm{Goethite}, \mathrm{FeOOH} ; \mathrm{Aqueous}$ phase, $\mathrm{H}_{2} \mathrm{O}, \mathrm{CO}_{2}, \mathrm{O}_{2}$. 
temperatures. The large fluoride concentrations result from equilibrium of the calcium-deficient groundwater with the mineral fluorite (Robertson 1984).

Geochemical models developed from major-ion data show that reactions occurring along flow paths are weathering of plagioclase, potassium feldspar and hornblende, precipitation of calcite and formation of montmorillonite and goethite. Reactions were identified by mass-balance calculations using the program, BALANCE (Parkhurst, Plummer \& Thorstenson 1982). Initial and final water compositions along a flow path and selected reactant and product phases are used to define reactions and mass transfer (amounts of minerals that precipitate or dissolve) that result from these reactions. Reactant phases used in the models (Table 2) were selected to be consistent with the Galiuro volcanic complex (Krieger 1979, 1980). The most significant observation in Table 2 is the similarity of the mass transfer of the primary aluminosilicates, although the chemistry and dissolved constituents differ significantly along flow paths. The major differences in water chemistry can be attributed to the dissolution of halite and gypsum. Chloride, sulfate and dissolved solids, for example, increase by factors of 5, 8 and 2, respectively, between the waters of Sample 3 at the beginning of the confined aquifer system in the southern part of the basin, to Sample 9 in the north near Mammoth. This similarity of the mass transfer of plagioclase, hornblende and potassium feldspar, and of the total mass transfer of the aluminosilicates, in view of the differing water compositions, indicates that a common geochemical process is occurring in the basin.

\section{Carbon Isotopes}

Large quantities of water are stored in the interstitial voids of the sediments. Compared with the volume in storage, small quantities of water enter, move through and leave the system. Water enters the groundwater system as surface water infiltrating along the mountain fronts and along streams that emerge from the consolidated rocks. The model for ${ }^{14} \mathrm{C}$ movement makes three assumptions regarding the hydrological flow system: 1) the general flow path of the groundwater is known; 2) the aquifer is confined and downward leakage does not occur; 3 ) a steady-state piston flow (no dispersion) adequately describes the flow system. These assumptions appear to be met in the confined aquifer. As interpreted from the major-element chemistry and supported through the ${ }^{14} \mathrm{C}$ and chemical modeling, distinct flow paths occur between the recharge near the Galiuro Mountains and the discharge along the basin center. Flowing wells along the axis in the basin confirm that the system is confined. Phillips, Tansey and Peeters (1989) showed that dispersive processes do not significantly affect the ${ }^{14} \mathrm{C}$ distribution in a similar confined aquifer in the San Juan basin, northwest New Mexico.

Soil gas and soil contents of ${ }^{14} \mathrm{C}$ and ${ }^{13} \mathrm{C}$ determined for several samples in the region were used in the ${ }^{14} \mathrm{C}$ model. The $\delta^{13} \mathrm{C}$ values for seven samples of $\mathrm{CO}_{2}$ soil gas sampled in winter and summer near the Galiuro Mountains ranged between -18.1 and $-23.1 \%$ and averaged $-19.9 \%$. These values are typical of stable-isotope compositions found in other parts of Arizona and arid areas of the West (Parada 1981; Wood \& Petraitis 1984; Thorstenson et al. 1990). The $\delta^{13} \mathrm{C}$ for soil and aquifer carbonates exhibit a larger variation. Soil analyzed for ${ }^{13} \mathrm{C}$ content in nearby basins showed values from -1.8 to $-7.8 \%$ and averaged about $-4.5 \%$ (Robertson 1991). The ${ }^{14} \mathrm{C}$ activities of two samples of solid carbonate from a nearby basin were $16 \mathrm{pMC}$ along a wash channel extending into the basin and $4.5 \mathrm{pMC}$ from well cuttings at a depth of $92 \mathrm{~m}$. The ${ }^{14} \mathrm{C}$ activities of two soil samples from the Huachuca Mountains near Huachuca Spring in the upper basin were 66.3 and $88.3 \mathrm{pMC}$. The ${ }^{14} \mathrm{C}$ activity of soil calcites determined in nine samples by Wallick (1973) ranged from $<0.67$ to $66.0 \mathrm{pMC}$ and averaged $24 \mathrm{pMC}$. The wide range of ${ }^{14} \mathrm{C}$ and ${ }^{13} \mathrm{C}$ contents illustrates the complexity of the carbon chemistry in arid areas. 
For the ${ }^{14} \mathrm{C}$ modeling, the chemical and isotope data from Huachuca Spring in the upper San Pedro basin (Fig. 1) were used as the recharge-water composition (Sample 1 in Table 1) because no wells were available for sampling in the lower basin. The spring issues from the alluvium near the contact of the Huachuca Mountains. Except for lower silica and higher tritium content, the spring water has a chemical and isotopic composition very similar to an average composition determined in recharge areas from nine basins in the region (Robertson 1991). The isotopic composition of the total dissolved inorganic carbon (TDIC) can be determined from the general isotope mass-balance equation, from which the $\delta^{13} \mathrm{C}$ value of the TDIC from more than one source can be calculated

$$
\delta^{13} \mathrm{C}_{\text {final }}=\frac{\sum_{0}^{\mathrm{i}}\left(\mathrm{mC}_{\mathrm{i}}\right)\left(\delta^{13} \mathrm{C}_{\mathrm{i}}\right)}{\mathrm{i}}
$$

where

$\mathrm{mC}_{\mathrm{i}}=$ molality of added TDIC from the $\mathrm{i}^{\text {th }}$ source and $\delta^{13} C_{i}=\delta^{13} \mathrm{C}$ value of added TDIC from the $i^{\text {th }}$ source.

Evolution of the recharge area is largely determined by the partial pressure of soil $\mathrm{CO}_{2}\left(\mathrm{pCO}_{2}\right)$ and dissolution of calcite and, if present, dolomite. Infiltrating water equilibrates with soil $\mathrm{CO}_{2}$ and dissolves calcite and dolomite and weathers silicate minerals. The degree of silicate weathering probably is also determined by the availability of $\mathrm{CO}_{2}$-bearing water and the time of contact with silicate minerals.

Under closed conditions, $\mathrm{pH}$ increases from about 7 in the recharge area to 9.5 downgradient; TDIC content decreases from near $6 \mathrm{mmol} \mathrm{liter}^{-1}$ to less than $2 \mathrm{mmol} \mathrm{liter}^{-1}$ downgradient (Table 1). The change in TDIC along the flow path is calculated from TDIC determined by the speciation equilibrium program, WATEQ4F (Ball, Nordstrom \& Zachmann 1987). Loss of total carbon results from precipitation of calcite; groundwater temperatures were below $50^{\circ} \mathrm{C}$ and outgassing of $\mathrm{CO}_{2}$ was not observed. $\mathrm{pCO}_{2}$ of the groundwater decreases significantly downgradient and $\mathrm{pH}$ values increase, owing to silicate hydrolysis, although calcite precipitation is an acid-producing reaction. Dissolved $\mathrm{CO}_{2}$ (aq) decreases downgradient as hydrogen ions are consumed and carbonic acid dissociates to form bicarbonate ions, which are precipitated as calcite in response to increases in $\mathrm{pH}$ and temperature.

The residence time of the ${ }^{14} \mathrm{C}$ in groundwater, the time elapsing from recharge when the groundwater became isolated from atmospheric and soil $\mathrm{CO}_{2}$ to points downgradient, is determined by the radioactive-decay equation

$$
\mathrm{t}=\frac{5730}{\ln 2} \ln \frac{\mathrm{A}_{\mathrm{i}}}{\mathrm{A}_{\text {meas }}}
$$

where $t$ is years before present, 5730 is the half-life of ${ }^{14} \mathrm{C}, \mathrm{A}_{\text {meas }}$ is the ${ }^{14} \mathrm{C}$ activity of the TDIC determined in the laboratory, and $\mathrm{A}_{\mathrm{i}}$ is the initial activity corrected for rock-water reactions within the aquifer before any radioactive decay has occurred. Because the age of TDIC cannot be directly translated into the age of the water, a correction must be applied to obtain the age of the groundwater. The correction accounts for hydrochemical effects of dilution of soil $\mathrm{CO}_{2}$ by non- 
radiogenic carbon (congruent reactions) and by precipitation and dissolution of carbonate minerals (incongruent reactions).

The correction method selected for determining $A_{i}$ is the equation derived by Wigley, Plummer and Pearson (1978) and used by Plummer, Parkhurst and Thorstenson (1983) to evaluate the carbon evolution and dating of groundwaters

$$
\delta^{13} C_{\text {final }}=\frac{\left[\left(\tilde{\beta} \delta^{13} C_{0}-\overline{\delta^{13} C^{*}}+\frac{\varepsilon p s}{\Gamma^{T}}\right)\left(\frac{m C}{m C_{0}}\right)^{\xi}-\frac{\varepsilon p s}{\Gamma^{T}}+\delta^{13} C^{*}\right]}{\tilde{\beta}}
$$

where

$$
\begin{aligned}
& \tilde{\beta}=1+\left(\frac{10^{-3} \varepsilon p s}{\Gamma^{\mathrm{T}}}\right), \text { and } \\
& \frac{\delta^{13} \mathrm{C}_{0}=\text { isotopic composition of initial water }}{\delta^{13} \mathrm{C}^{*}=\text { average isotopic composition of carbon input }} \\
& \Gamma^{\mathrm{T}}=\text { ratio of total carbon input to carbon precipitated } \\
& \varepsilon p s=\text { isotopic fractionation factor } \\
& \mathrm{mC}=\Sigma \mathrm{CO}_{2} \text { in solution } \\
& \mathrm{mC}_{0}=\Sigma \mathrm{CO}_{2} \text { in initial solution } \\
& \xi=\frac{\tilde{\beta} \Gamma^{\mathrm{T}}}{1-\Gamma^{\mathrm{T}}}
\end{aligned}
$$

The method should be the most applicable for the system under study, as the TDIC changes significantly along the flow path and accentuates the significance of the incongruent reactions. The only carbon source in the aquifer detected by XRD is calcite and, being considerably richer in ${ }^{13} \mathrm{C}$ than the predominantly soil-gas-derived TDIC, will enrich the TDIC in ${ }^{13} \mathrm{C}$ proportional to the amount of dissolved calcite. The amount of dissolved aquifer calcite and subsequent precipitated calcite (as the net change along the flow path is a decrease in TDIC) is calculated through the term, $\Gamma^{\mathrm{T}}$, in Equation 4 by deriving the observed $\delta^{13} \mathrm{C}_{\text {final }}$ of the TDIC. The $\delta^{13} \mathrm{C}$ values of $-12.7 \%$ and $-4.5 \%$ were used for the initial and for the average for the dissolving carbonate, respectively, and $5.62 \mathrm{mmol} \mathrm{liter}^{-1}$ was used for the molality of the initial TDIC.

Figure 5 illustrates the amount of dissolved aquifer calcite required to derive the $\delta^{13} \mathrm{C}$ of the final water. Thus, although a net loss in TDIC occurs along the flow path between the Galiuro Mountains and the basin axis (Table 1), calcite, according to the evolution of the ${ }^{13} \mathrm{C}$ content, is dissolving at points along the flow path. Calcite precipitation is a major geochemical reaction of confined aquifers in the region. The linear trend and intercept of the values in Figure 5 indicate that the variation in the $\delta^{13} \mathrm{C}$ of the carbonates is not large and that $-4.5 \%$ is a representative value.

Equation 4 is used to calculate $\mathrm{A}_{\mathrm{i}}$, the ${ }^{14} \mathrm{C}$ activity before any radioactive decay occurred, in a manner similar to the calculation of $\delta^{13} \mathrm{C} . \delta^{14} \mathrm{C}=10 \mathrm{~A}-1000$, where $\mathrm{A}$ is $\mathrm{pMC}$. A value of 87 pMC was used for the initial activity, and 0 and $20 \mathrm{pMC}$ were used for the average activity of the dissolving carbonate. Values of 0 and $20 \mathrm{pMC}$ were selected to represent a probable range in ${ }^{14} \mathrm{C}$, 


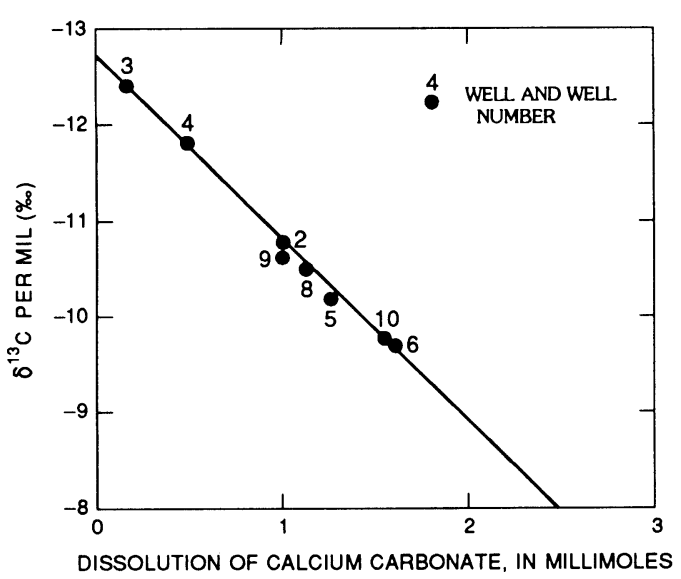

Fig. 5. Relation of dissolved aquifer carbonate to $\delta^{13} \mathrm{C}$ of total dissolved carbon

as available data show the solid carbonates contain appreciable ${ }^{14} \mathrm{C}$. Fractionation between bicarbonate and calcite was not considered. This fractionation effect, although small, about $1 \%$, is not experimentally well defined (Fritz et al. 1989; Turner 1982). Turner (1982) has shown experimentally that under conditions of kinetic fractionation, the solid phase may even become depleted in the heavier isotope through diffusion during crystal growth, thus enriching the solution in ${ }^{13} \mathrm{C}$. For comparison purposes, ages for some samples were calculated using a fractionation of $1 \%$, which depletes the solution in ${ }^{13} \mathrm{C}$ and results in a younger age.

Corrected ${ }^{14} \mathrm{C}$ ages (Table 3) show that groundwater is more than $12 \mathrm{ka} \mathrm{BP}$ along the central axis of the basin. Sample 6, with an age of 6 to $7 \mathrm{ka}$ BP, is younger than Sample 5 upgradient. This sample has been diluted by younger waters from the flood-plain aquifer, indicated by detectable tritium, by increases in TDIC and ${ }^{14} \mathrm{C}$ content, and by decreases in sulfate, chloride and sodium relative to Well 5. The age of this sample is not taken into consideration as the modeling is based on chemical evolution under confined conditions and not on mixing. Sample 7, which contains atmospheric bomb carbon, is from a perched water table in the recharge area near the Galiuro Mountains. The chemistry of the infiltrating water has not yet evolved to the composition found in most recharge areas. The hypothesis that carbonate mineral dissolution is absent is supported by the ${ }^{13} \mathrm{C}$ content and by the significant undersaturation with respect to calcite and dolomite. Excluding Wells 6 and 7, the large and similar groundwater ages give evidence of a geochemically closed system. ${ }^{14} \mathrm{C}$ ages do not increase downvalley but only along flow paths from the Galiuro Mountains to the basin center. ${ }^{14} \mathrm{C}$ isochrons parallel the Galiuro Mountains similarly to the potentiometric surface, but indicate that little water is moving downvalley.

Incongruent reactions of carbon are evident from the small but significant change of $\delta^{13} \mathrm{C}$ in some samples under conditions of decreasing content in TDIC (Table 3). Large decreases in total carbon downgradient require significant dissolution of aquifer calcite to achieve the observed enrichment of ${ }^{13} \mathrm{C}$. (Decreases in TDIC require extensive congruent reactions to account for the enrichment of ${ }^{13} \mathrm{C}$ whereas TDIC increases could, in some cases, be satisfied by dilution of small amounts of aquifer calcite.) The low ${ }^{13} \mathrm{C}$ contents of Wells 3 and 4 , however, show little change since recharge and have geochemical and hydrological significance. The $\delta^{13} \mathrm{C}$ value is similar to that of present groundwater in recharge areas. Thus, little change in isotopic composition occurred during the last $10 \mathrm{ka}$, which is extremely important for interpreting ${ }^{14} \mathrm{C}$ measurements. These older waters are comparable in age to wells downvalley, which are enriched in ${ }^{13} \mathrm{C}$ (Wells 5, 8, 9 and 10). The hydrological nature of the flow system, although varying from point to point in hydrological properties, should be regionally uniform for purposes of age comparison. This regional uniformity 
TABLE 3. Initial ${ }^{14} \mathrm{C}$ activity and ages of groundwater in the lower San Pedro basin. (Ages were calculated using $\delta^{13} \mathrm{C}$ of $-4.5 \%$ aquifer calcite)

\begin{tabular}{cclclc}
\hline $\begin{array}{c}\text { Well } \\
\text { (spring) no. }\end{array}$ & $\begin{array}{c}\left.\Delta \text { TDIC }^{2} \text { liter }^{-1}\right) \\
\text { (mmol }\end{array}$ & $\begin{array}{l}\mathrm{A}_{1}{ }^{*} \\
(\mathrm{pMC})\end{array}$ & $\begin{array}{l}\text { Age } \\
(\mathrm{ka} \mathrm{BP})\end{array}$ & $\begin{array}{l}\mathrm{A}_{1}{ }^{* *} \\
(\mathrm{pMC})\end{array}$ & $\begin{array}{l}\text { Age } \\
(\mathrm{ka} \mathrm{BP})\end{array}$ \\
\hline 1 & 5.62 & 87 & Modern & 87 & Modern \\
2 & 3.19 & 66.9 & 4.7 & 71.5 & 5.2 \\
3 & 3.36 & 83.8 & 10.5 & 84.5 & 10.6 \\
$3^{\dagger}$ & 3.36 & 73.3 & 9.4 & 76.5 & 9.7 \\
4 & 3.23 & 77.4 & 10.4 & 79.6 & 10.6 \\
5 & 3.70 & 60.5 & 7.8 & 66.6 & 8.6 \\
6 & 3.62 & 55.1 & 6.4 & 62.4 & 7.4 \\
7 &..- &..- & Modern &..- & Modern \\
8 & 3.59 & 63.7 & 10.1 & 69.0 & 10.8 \\
9 & 3.84 & 64.7 & 9.9 & 69.8 & 10.5 \\
10 & 3.51 & 56.3 & 15.2 & 63.3 & 16.1 \\
$10^{\dagger}$ & 3.51 & 43.5 & 13 & 53.5 & 14.7 \\
\hline
\end{tabular}

"Initial activity calculated using $0 \mathrm{pMC}$ for aquifer calcite.

**Initial activity calculated using $20 \mathrm{pMC}$ for aquifer calcite.

${ }^{\dagger}$ Fractionation $\delta^{13} \mathrm{C}_{\mathrm{HCO}}-\delta^{13} \mathrm{C}_{\mathrm{CaCO}}=-1 \% 0$

is evident in the gradient of the potentiometric surface between the Galiuro Mountains and the discharge area (Fig. 4).

Groundwater ages determined from the ${ }^{14} \mathrm{C}$ data agree with mass-transfer values calculated for chemical evolution of the groundwater along the flow paths. No significant increase in silicate weathering is observed along the $32 \mathrm{~km}$ between samples 3 and 10, suggesting that little water moves downvalley. Weathering occurs only along flow paths from the Galiuro Mountains to the basin center, as does the increase in groundwater ages.

\section{Groundwater Velocities}

These adjusted ${ }^{14} \mathrm{C}$ ages can be used to determine velocity of groundwater flow and hydraulic conductivity of the aquifer. Velocity of groundwater flow was calculated by assuming that the ${ }^{14} \mathrm{C}$ age is the time required for water to flow from recharge areas to sampling point. An assumed horizontal flow line was measured from the contact of the alluvium-Galiuro Mountains to the sampled well. Distance divided by age yields groundwater velocities, which were calculated to be about $1 \mathrm{~m} \mathrm{yr}^{-1}$. These groundwater velocities can be used to calculate the hydraulic conductivity by using the following equation

$$
\mathrm{K}=\frac{\mathrm{V} \Theta}{\mathrm{I}},
$$

where $\mathrm{K}$ is hydraulic conductivity, $\mathrm{V}$ is groundwater velocity, I is gradient, and $\Theta$ is porosity. Gradient is the head difference of the potentiometric surface divided by the distance to the sampling point. Porosity of 0.30 was assigned to the alluvium as a representative value (Anderson, Freethey \& Tucci 1990).

The hydraulic-conductivity values calculated for the confined aquifer are about $3.5 \times 10^{-7}$ to 7.0 $\times 10^{-7} \mathrm{~m} \mathrm{~s}^{-1}$, and are about an order of magnitude smaller than expected using other methods (Anderson, Freethey \& Tucci 1990). The smaller-than-expected values may be caused by the thick 
confining layer overlying the discharge area along the San Pedro River. The confined aquifer has no major discharge or withdrawal in this area along the river, other than upward leakage.

\section{CONCLUSIONS}

Chemical and isotope data were used to evaluate the hydrological flow system in a confined aquifer of the lower San Pedro basin, southeast Arizona, USA. The flow systems in these alluvial basins are among the most difficult to evaluate because of complex structure and stratigraphy and lack of areal hydrological data. Because of their regional implication, isotopic and geochemical models can provide more insight into the flow systems than traditional hydrological methods. Areas of recharge and discharge were defined by the models using distribution of the isotope and chemical data. Corrected ages show that the groundwater is greater than $10 \mathrm{ka} \mathrm{BP}$ and does not increase in age downvalley. The ${ }^{14} \mathrm{C}$ interpretation of the flow system agrees with reactions and mass transfer of the chemical model.

A major problem encountered in correcting the measured ${ }^{14} \mathrm{C}$ ages is the lack of precise knowledge of ${ }^{14} \mathrm{C}$ and ${ }^{13} \mathrm{C}$ contents of the solid phase. Laboratory studies indicate that these contents vary widely throughout the region. The ${ }^{13} \mathrm{C}$ content of the soil gas varies less and may have been constant during the last $10 \mathrm{ka}$. Hydraulic-conductivity values calculated from the ${ }^{14} \mathrm{C}$ ages are about an order of magnitude smaller than expected. These low values may be caused, in part, by the thick confining layer overlying the discharge area along the San Pedro River. Using isotopically lighter carbonates and a fractionation effect between bicarbonate and carbonate would yield younger ages and slightly larger hydraulic conductivities, whereas increases in the ${ }^{14} \mathrm{C}$ content of the carbonates would yield older ages and smaller conductivities.

\section{REFERENCES}

Anderson, T. W., Freethey, G. W. and Tucci, P. 1990 Geohydrology and water resources of alluvial basins in south-central Arizona and parts of adjacent States. U.S. Geological Survey Open-File Report 89-378: 99 p.

Ball, J. W., Nordstrom, D. K. and Zachmann, D. W. 1987 WATEQ4F - A personal computer Fortran translation of the geochemical model WATEQ2 with revised data base. U.S. Geological Survey Open-File Report 87-50: 108 p.

Barnes, I. 1964 Field measurement of alkalinity and pH. U.S. Geological Survey Water-Supply Paper 1535-H: $17 \mathrm{p}$.

Brown, E., Skougstad, M. W. and Fishman, M. J. 1970 Methods for collection and analysis of water samples for dissolved minerals and gases. U.S. Geological Survey Techniques of Water Resources Investigations 5: $160 \mathrm{p}$.

Fritz, P., Fontes, J.-Ch., Frape, S. K., Louvat, D., Michelot, J.-L. and Balderer, W. 1989 The isotope geochemistry of carbon in groundwater at Stripa. Geochimica et Cosmochimica Acta 53: 1765-1775.

Halpenny, L. C. and others 1952 Ground water in the Gila River basin and adjacent areas, Arizona - A summary. U.S. Geological Survey Open-File Report: $224 \mathrm{p}$.

Krieger, M. H. 1979 Ash-flow tuffs of the Galiuro Volcanics in the northern Galiuro Mountains, Pinal County, Arizona. U.S. Geological Survey Profession- al Paper 1104: $32 \mathrm{p}$.

1980 Zeolitization of Tertiary tuffs in lacustrine and alluvial deposits in the Ray-San Manuel area, Pinal and Gila Counties Arizona. In Shorter Contributions to Mineralogy and Petrology, 1979. U.S. Geological Survey Professional Paper 1124-D: 11 p.

Laney, R. L. and Hahn, M. E. 1987 Hydrogeology of the eastern part of the Salt River Valley area, Maricopa and Pinal Counties, Arizona. U.S. Geological Survey Water-Resources Investigations: 86-4147.

Parada, C. B. (ms.) 1981 Isotopic composition of soil carbon dioxide in the Tucson basin. M.A. thesis, University of Arizona: $85 \mathrm{p}$.

Parkhurst, D. L., Plummer, L. N. and Thorstenson, D. C. 1982 BALANCE - A computer program for calculating mass transfer for geochemical reactions in ground water. U.S. Geological Survey Water-Resources Investigations 82-14: $29 \mathrm{p}$.

Phillips, F. M., Tansey, M. K. and Peeters, L. A. 1989 An isotopic investigation of groundwater in the central San Juan Basin, New Mexico - Carbon 14 dating as a basis for numerical flow modeling. Water Resources Research 25(10): 2259-2273.

Plummer, L. N., Parkhurst, D. L. and Thorstenson, D. C. 1983 Development of reaction models for groundwater systems. Geochimica et Cosmochimica Acta 47: 665-686.

Pool, D. R. 1986 Aquifer geology of alluvial basins of 
Arizona. In Anderson, T. W. and Johnson, A. I., eds., Regional Aquifer Systems of the United States, Southwest Alluvial Basins of Arizona. American Water Resources Association Monograph Series 7: 25-36.

Robertson, F. N. 1984 Solubility controls of fluorine, barium and chromium in ground water in alluvial basins of Arizona. In Hitchon, B. and Wallick, E. I., eds., Practical Applications of Groundwater Geochemistry. Proceedings of the 1st Canadian/American Conference on Hydrogeology: 96-102.

1991 Geochemistry of ground water in alluvial basins of Arizona and adjacent parts of Nevada, New Mexico, and California. U.S. Geological Survey Professional Paper 1406-C: $90 \mathrm{p}$.

Roeske, R. H. and Werrell, W. L. 1973 Hydrological conditions in the San Pedro River Valley, Arizona, 1971. Arizona Water Commission Bulletin 4: $76 \mathrm{p}$.

Thorstenson, D. C., Weeks, E. P., Haas, H. and Woodward, J. C. 1990 Physical and chemical characteris- tics of topographically affected airflow in an open borehole at Yucca Mountain, Nevada. In Proceedings of the Topical Meeting on Nuclear Waste Isolation in the Unsaturated Zone. America Nuclear Society, Inc., Grange Park, Illinois.

Turner, J. V. 1982 Kinetic fractionation of carbon-13 during calcium carbonate precipitation. Geochimica et Cosmochimica Acta 46: 1183-1191.

Wallick, E. I. (ms.) 1973 Isotopic and chemical considerations in radiocarbon dating of groundwater within the arid Tucson basin, Arizona. Ph.D. dissertation, University of Arizona: $184 \mathrm{p}$.

Wigley, T. M. L., Plummer, L. N. and Pearson, F. J., Jr. 1978 Mass transfer and carbon isotope evolution of natural water systems. Geochimica et Cosmochimica Acta 42: 1117-1139.

Wood, W. W. and Petraitis, M. J. 1984 Origin and distribution of carbon dioxide in the unsaturated zone of the Southern High Plains. Water Resources Research 20(9): 1193-1208. 